\title{
Workers: New Developments in Labor History since the 1980 s
}

\author{
Jan Lucassen
}

In 1971, at the age of 19, Marcel van der Linden-who took his M.A. in sociology at Utrecht University-had already started his publishing career, initially dealing with topics concerning political economy. In 1983 he joined the International Institute of Social History (IISH) as a member of the section International Review of Social History and publications, headed by Arend van Woerden. This was just before the IISH underwent a major reorganization under Eric Fischer (in charge from 1984 to 1993), in which the regional "cabinets" were discontinued and replaced by functional departments, including a separate research department. ${ }^{1}$ The "cabinet" staff who wished to, were given the option to become assistant researchers or researchers, which initially entailed the continuation of their source publications underway. However, Fischer wanted more: he felt the IISH research department should concentrate on analytical historical research in close connection with historical departments at universities.

Based at Utrecht University and a former colleague of Eric Fisher, in 1988 I was invited to put into practice this new research policy, which turned out not to be an easy task. However, by finding new funding and by offering parttime positions to colleagues who at the same time were able to maintain their professorial chairs at Dutch universities (for example Tony Saich for Chinese history, Eric Jan Zürcher for Turkish history, and later on Willem van Schendel for South-Asian history), a new start gradually became feasible. In this process it turned out that at the Institute, although in a different department, in Marcel I would find my natural ally. In 1987 he had succeeded Van Woerden to

1 Jan Lucassen, Tracing the Past. Collections and research in social and economic history: The International Institute of Social History, the Netherlands Economic History Archive and related institutions (Amsterdam, 1989), 47-57; Jaap Kloosterman and Jan Lucassen, Rebels with a Cause. Five centuries of social history collected by the IISH (Amsterdam, 2010), 24-25; for details, see the Annual Reports of the Institute, accessible through https://socialhistory.org/en/ annualreports. 
become head of the Publications Section and Executive Editor of the International Review of Social History (IRSH). Over the years our cooperation became so close that the research and publications departments were merged in 1993, with me as head and Marcel as my deputy. After ten years, Marcel-though continuing his responsibilities at the $I R S H$ - had fully become involved in the IISH research.

What were the main issues involved in setting up this new department? As a social historian of the early modern period with a strong inclination toward economic history, I felt an urge to expand the traditional field of interest of the Institute. By concentrating on source publications of documents acquired by the IISH since its inception in 1935, the emphasis up to that time had been placed clearly on Europe's leftist trade union and political movements in the period from 1870 to 1918 , in particular the German and French-speaking countries, the Netherlands and its colonies, and also Russia. A rich field, without doubt, but at the same time only partially covering the history of work as I was used to thinking of it. The topics I had studied up to that time- the seasonal workers of Europe between 1600 and 1800 and the Moroccan and Turkish "guest workers" and immigrants more in general since 1600-only overlapped very partially with the traditional interests of the IISH. ${ }^{2}$ Of course I could have accepted this and switched my interests, but I considered that was not the right path to follow; and the directorate (Eric Fischer, Jaap Kloosterman, and Henk Wals) fully agreed.

Instead, I developed the idea that it would be worthwhile to adopt a much wider definition of work than was usual in labor history as practiced at that time, which automatically encompassed pre-industrial and barely industrialized parts of the world. ${ }^{3}$ This endeavor developed into the overarching project

2 Jan Lucassen, Migrant Labour in Europe 1600-19oo. The Drift to the North Sea (London, 1987) (original Dutch edition 1984); Jan Lucassen and Rinus Penninx, Newcomers. Immigrants and their Descendants in the Netherlands 1550-1995 (Amsterdam, 1997) (original Dutch edition 1985).

3 In 1989 I defined the field as follows: "The aim is to promote research on labour history in the broadest sense of the word. This comprises the history of all kinds of labour though the emphasis lies on workers, whether in paid employment, contract work or in slavery. The history of labour breaks down into three aspects: labour market; labour relations; and the organization of labour and of workers (the 'modern' socialist, anarchist, Christian, liberal and fascist labour movements, as well as workers' organizations based on ethnic, racial, gender, etc. principles). The modern and contemporaneous period will be the focus, with an emphasis on the 19th and 2oth centuries. In principle, this ambitious programme will encompass the whole world." (Lucassen 1989, 51-56). For addressing the earlier centuries, see Jan Lucassen, Jan, Jan Salie en diens kinderen. Vergelijkend onderzoek naar continü̈teit en discontinü̈teit in de ontwikkeling van arbeidsverhoudingen (Amsterdam, 1991); Catharina Lis, Jan Lucassen, and 
of the Research Department of the IISH on Global Labour History under the directorship of myself, my successor Marcel (from 2001 to 2014), and which is still currently practiced at the IISH.

What made Marcel my natural ally on this path? For me it was his methodological angle as a sociologist: always looking for conceptual precision, and also believing in the major advantages of the comparative method. This had already become clear from the conference theme of the fiftieth anniversary of the IISH in 1986: a systematic comparison of internationalism in the labor movement between 1830 and 1940, the proceedings of which were co-edited by Marcel. ${ }^{4}$

This essay is not intended to offer a detailed reconstruction of our longstanding cooperation (and others, in the first place Lex Heerma van Voss 5 ), but instead focuses on its results. The development of three topics in particular deserves closer scrutiny: the definitions of what is work and who is a worker, the taxonomy of labor relations, and the long-term history of one specific form of labor relations more in particular, specifically wage work.

\section{Definition Questions}

In our search for a definition of work encompassing pre-industrial and nonindustrialized societies, we were happy to discover the approach of Charles and Chris Tilly as published in 1998 , and we immediately embraced it. ${ }^{6}$ According to them:

Hugo Soly, eds., "Before the Unions. Wage earners and collective action in Europe, 1300-1850," International Review of Social History, Supplement 2 (1994). See also Karel Davids and Jan Lucassen, eds., A Miracle Mirrored. The Dutch Republic in European Perspective (Cambridge, 1995), xvii-xviii.

4 Frits van Holthoon and Marcel van der Linden, eds., Internationalism in the Labour Movement 1830-1940 (Leiden, 1988), followed by Marcel van der Linden and Jürgen Rojahn, eds., The Formation of Labour Movements 1870-1914. An International Perspective (Leiden, 1990). About ten years later, he added a certain emphasis on "interconnections" or "entanglements."

5 Risking doing an injustice to many others, I would like to also mention the intellectual input from Aad Blok and Willem van Schendel, and somewhat later from Karin Hofmeester, Jan Kok, and Gijs Kessler.

6 Marcel van der Linden and Jan Lucassen, Prolegomena for a Global Labour History (Amsterdam, 1999), 8; Chris Tilly and Charles Tilly, Work Under Capitalism (Boulder, CO, 1998), 22-23. Charles Tilly played a dominant role in the International Advisory Board of the IRSH, established in 1990, and in the same year Marcel and I visited his New School for Social Research (then also joined by Eric Hobsbawm). See also Marcel van der Linden, "Charles Tilly's Historical Sociology," International Review of Social History 54, no. 2 (August 2009): 237-274. 
Work includes any human effort adding use value to goods and services. However much their performers may enjoy or loathe the effort, conversation, song, decoration, pornography, table-setting, gardening, housecleaning, and repair of broken toys, all involve work to the extent that they increase satisfactions their consumers gain from them. Prior to the twentieth century, a vast majority of the world's workers performed the bulk of their work in other settings than salaried jobs as we know them today. Even today, over the world as a whole, most work takes place outside of regular jobs. Only a prejudice bred by Western capitalism and its industrial labor markets fixes on strenuous effort expended for money payment outside the home as "real work," relegating other efforts to amusement, crime, and mere housekeeping ... Despite the rise of takeouts, fast foods, and restaurant eating, unpaid preparation of meals probably constitutes the largest single block of time among all types of work, paid or unpaid, that today's Americans do.

However, in those days mainstream labor historians - notwithstanding their general leftist political inclinations - had also come under the spell of "Western capitalism" and concentrated almost without exception on the male industrial worker, in particular in the West, and more specifically in England and its white settler colonies.

That, however, had not always been the case. ${ }^{7}$ Many authors in the nineteenth century were interested in the history of work from the beginning of mankind as it was known by then: mainly work in Europe, North Africa, Western, and South Asia from Classical Antiquity onwards. Within these confines, most space was devoted to market economies with the unpaid work of slaves as well as paid work by free laborers. Included were all types of paid workers, such as artisans, farmers and their personnel, peasants, people engaged in cottage industries, miners, and industrial workers. The subsequent conceptual and geographical narrowing down of the history of work and its final liberation may best be followed throughout three stages in the debate on the origins of market economies: first, medieval market economies in Europe, second, exclusive English origins, and third, Eurasian origins from Antiquity onward.

7 Jan Lucassen, "Writing Global Labour History c. 1800-1940: A Historiography of Concepts, Periods and Geographical Scope," in Global Labour History. A State of the Art, ed. Jan Lucassen (Bern, 2006), 39-89. 
2.1 The Origins of Market Economies in Europe: Marx and Pirenne

It is generally accepted that the traditional market economy of the Roman Empire was radically interrupted in Western Europe for half a millennium. Therefore most authors interested in its development start their narratives after 1000 CE. Marx' historical sketch of the transition from feudalism to a society characterized by markets is somewhat vague and follows the mainstream historical account of his days. ${ }^{8}$ In this narrative, a period of feudalism was followed by one in which "capital" came to dominate first Europe and subsequently the rest of the world. It started with medieval Genoa and Venice, which were succeeded by the Dutch Republic, and finally by England. Whereas Italy and Holland were dominated by "commercial capital," it was "industrial capital" that took the lead in England. ${ }^{9}$ Karl Marx himself did not speak of "capitalism" or of "commercial capitalism," but after him the latter term became generally accepted by Marxians and non-Marxians alike. Thanks to his Dutch family connections, Marx elaborates a little on the Dutch Republic. Parallel to what he observed in his own times, he was convinced that dominated by industrial capital, by 1648 the common people in the Dutch Republic were already more over-worked, impoverished, and brutally suppressed than anywhere else in Europe. On top of this, the Dutch exploited their subjects in Asia and their slave plantations in the West Indies. In addition to the rise of "capital" in his triplet of Northern Italy, the Dutch Republic, and England he stressedin line with Thomas Babington Macauly's History of England-the demise of serfdom and the rise in fifteenth-century England of peasants, partially wage workers for the powerful farmers.

The first professional historian to study the origins of market economies at length was Henri Pirenne, in a paper read at the International Congress of Historical Studies in London in $1913 .{ }^{10}$ In this work, he formulated a "hypothesis" (as he modestly states in his opening sentence) about the origin and nature of "the capitalist, the holder of capital" from the Middle Ages onward. He borrows

8 The body of literature on this topic is vast. A useful overview can be found in R.J. Holton, The Transition from Feudalism to Capitalism (Houndmills, Basingstoke, 1985), Ch. 3. More recently, Jürgen Kocka, "Introduction," in Capitalism. The Reemergence of a Historical Concept, eds. Jürgen Kocka and Marcel van der Linden (London, 2016), 1-10; Jürgen Kocka and Marcel van der Linden, eds., Capitalism. The Reemergence of a Historical Concept (London, 2016).

9 Piet Lourens and Jan Lucassen, "Marx als Historiker der niederländischen Republik," in Die Rezeption der Marxschen Theorie in den Niederlanden, ed. Marcel van der Linden (Trier, 1992), 430-454.

10 Henri Pirenne, "The Stages in the Social History of Capitalism," American Historical Review (1914): 494-515, reprinted in Class, Status and Power. A Reader in Social Stratification, eds. Reinhard Bendix and Seymour Martin Lipset (London, 1954), 501-517. 
his definition from Werner Sombart's Der moderne Kapitalismus (1902), but at the same time fiercely rejects Sombart's idea that capitalism started only with the Renaissance. That may be the conclusion that could be reached after the study of German medieval towns, but it certainly does not apply to Northern Italy and the Low Countries. According to Pirenne "capitalism is much older than we have ordinarily thought it." But how much older? Before 1200 there were not many towns in Western Europe and those few were far more devoted to commerce than to industry, however, among the wandering merchants and their associations Pirenne already finds traces of the spiritus capitalisticus in the eleventh century. After 1200, migration from countryside to town and occupational specialization had an opportunity "so that all Western Europe, in the course of the thirteenth century, blossoms forth in an abundance of large and small towns." Speculative individual capitalists took their chances first, and from then on economic developments had their own logic via the Industrial Revolution until the early twentieth century. For Pirenne "the Industrial Revolution was just a more intense form of earlier development."11

\subsection{Exclusive English Origins?}

Contrary to this broad-if still Eurocentric-picture, from the end of the nineteenth century in England a much narrower view gained ground, which concentrated on the industrial laborer. Its most famous and eloquent spokesmen were Edward P. Thompson and Eric Hobsbawm. Brilliant intellectuals from mostly excellent universities, the English Marxist historians in the postwar years wanted to show to their fellow citizens that they were not the slavish followers of a foreign ideology that had been realized in the Soviet Union. To the contrary, the cradle of capitalism stood right in their own "good old England," and the answer to capitalist exploitation also had to be formulated in the same place. Two debates in particular were devoted to this issue: from the 1940 s to the 1970s that on the transition from feudalism to capitalism, followed by the so-called Brenner debate.

If feudalism preceded capitalism - as maintained by Marx (and many contemporaries ${ }^{12}$ ) - the question arises as to what "prime mover" triggered this major transition, and at what time and place it occurred. Virtually all Marxist participants in the debate agree that we have to turn to late Mediaeval England

11 Richard Grassby, The Idea of Capitalism before the Industrial Revolution (Lanham, 1999), 16-17.

12 R.J. Holton, The Transition from Feudalism to Capitalism (Houndmills, Basingstoke, 1985), Ch. 1. 
to find the roots of that transition, but as to how and why that happened, opinions diverge widely. ${ }^{13}$

The British economist Maurice Dobb (1900-1976) who started the debate, thought that somewhere between the fourteenth and seventeenth century, feudalism failed because of internal weaknesses, mainly its inability to foster capital accumulation and innovation, and its over-exploitation of peasants. ${ }^{14}$ The American economist Paul Sweezy (1910-2004) did not agree and-relying on Henri Pirenne-instead suggested the prime mover lay in an exogenous shock caused by the blossoming of long-distance trade and the revival of towns in Western Europe, including England. The most important contributor to this debate was the medievalist Rodney Hilton (1916-2002) in his later career. With regard to the late medieval English Midlands, he concluded that "all the evidence suggests that the village economy based on the peasant household was considerably monetised."15 The importance of the market and of wage labor for the England as a whole he then contrasted, remarkably, with continental Europe. ${ }^{16}$

This "Transition Debate" culminated in the so-called Brenner debate, which started with an article by Robert Paul Brenner (born in 1943), published in 1976 in the British journal Past and Present. A number of colleagues reacted, followed by a rebuttal, originally published in $1982 .{ }^{17}$

Brenner's starting point is the Late Middle Ages and in particular the thirteenth century, where he discovers "divergent paths of class formation within feudal Europe."18 The English lords "as extractors of a surplus from their peasants" had a "superior self-organization" and were therefore more accomplished than their French counterparts "as feudal centralizers and feudal

13 The following after Rodney Hilton, ed., The Transition from Feudalism to Capitalism (London, 1976); Holton, The Transition from Feudalism; S.R. Epstein, "Rodney Hilton, Marxism and the Transition from Feudalism and Capitalism," Past and Present 195 (Supplement 2, 2007): 248-269.

14 Maurice Dobb, Studies in the development of capitalism (1946).

15 Rodney Hilton, The English peasantry in the later Middle Ages: The Ford lectures for 1973, and related studies (Oxford, 1975), 43-49 quoted by Epstein. Here, Hilton opposes Postan (a "Ricardo-Malthusian" pessimist according to Epstein) and indirectly Chayanov. See also Hilton, The Transition from Feudalism.

16 Hilton, The Transition from Feudalism, $155^{-158 .}$

17 T.H. Aston and C.H.E. Philpin, eds., The Brenner Debate. Agrarian Class Structure and Economic Development in Pre-Industrial Europe (Cambridge, 1985).

18 Aston and Philpin, The Brenner Debate, quotes on 231 and 226 (where Brenner confesses himself to be "a 'political' and 'voluntarist' Marxist"). 
accumulators." ${ }^{19}$ In the centuries that followed, the original differences between England and France, so Brenner stated, turned out to be persistent, as France was dominated by peasant possessors. ${ }^{20}$

Despite much eloquence, Robert Brenner, his supporters-among whom to a certain extent was Rodney Hilton - and his critics of all sorts (among others M.M. Postan, Guy Bois, and Emmanuel Le Roy Ladurie) were unable to convince each other. Further, after the fireworks the debate quickly petered out. ${ }^{21}$ Brenner did not produce any new evidence, let alone firm statistical proof. ${ }^{22}$ Instead, the debate shifted to political science. There it was most eloquently and most successfully propagated by Ellen Meiksins Wood (1942-2016). ${ }^{23}$ It also stuck to a narrow Eurocentrism, as amply demonstrated by James Morris Blaut:

So Brenner's theory has this simple geography: there is distance-decay of interest and relevance as we enlarge the scale, from rural England to England as a whole, to Western Europe as a whole, to Europe as a whole, to the world as a whole. The place where feudalism died and capitalism was born was a very small region indeed: rural England. ${ }^{24}$

This Eurocentrism was questioned at the same time from many sides, as is detailed in the next section.

19 Aston and Philpin, The Brenner Debate, 254, cf. also 238-241; 255 for earlier roots in "the 'political' organization already achieved by the Normans in Normandy" [sic].

20 Aston and Philpin, The Brenner Debate, 306. On the Continent he only accepts one case for the emergence of the capitalist system: late medieval Catalonia (Idem 49, 52).

21 This expression is found in Bas van Bavel, The Invisible Hand? How Market Economies have Emerged and Declined since AD 500 (Oxford, 2016), 272.

22 Robert Brenner, Merchants and Revolution. Commercial Change, political Conflict, and London's Overseas Traders, 1550-1653 (Princeton, 1993), 647-658, see also 33-50; Brenner in Chris Harman and Robert Brenner, "The Origins of Capitalism," International Socialism. A quarterly review of socialist theory 111 (2006): xxxx, http://isj.org.uk/ the-origins-of-capitalism/.

23 Ellen Meiksins Wood, "Capitalism, Merchants and Bourgeois Revolution: Reflections on the Brenner Debate and its Sequel," International Review of Social History 41 (1996): 209-232; Ellen Meiksins Wood, The Origin of Capitalism (New York, 1999); Ellen Meiksins Wood, The Origin of Capitalism. A Longer View (London/New York, 2002). Both she and Brenner also alienated other leftist scholars such as Paul Sweezy, Andre Gunder Frank, Perry Anderson, and Immanuel Wallerstein.

24 J.M. Blaut, Eight Eurocentric Historians (New York/London, 2000), 56; J.M. Blaut, "Fourteen ninety-two," Political Geography 11, no. 4 (1992): 355-412. For Wallerstein's narrow Eurocentrism see recently Immanuel Wallerstein, "Capitalism as an Essential Concept to Understand Modernity," in Capitalism. The Reemergence of a Historical Concept, eds. Jürgen Kocka and Marcel van der Linden (London: Bloomsbury, 2016), 187-204, here 188. 


\subsection{Eurasian Origins of Market Economies from Antiquity Onward}

Until the seventeenth and early eighteenth century, Europeans had paid serious attention to the economic achievements of countries outside Europe. Later the tide turned, and definitely so in the nineteenth century. ${ }^{25}$ After the Second World War, Eurocentrism was questioned by historians, first and foremost Braudel, as well as by political scientists such as Samir Amin, Andre Gunder Frank, and James Morris Blaut. Very recently, this new approach received a fresh impetus from-independently of each other-Sugihara and Austen, Van Bavel, and Kocka and Van der Linden. ${ }^{26}$

Fernand Braudel is, without any doubt, the historian who has most successfully paved the way for the acceptance of more than one origin of economic development. ${ }^{27} \mathrm{He}$ is neither the first nor the only historian to challenge the unicity of Western European history, but his writings from the start have been so seductive that they were able to beat the powerful but insular Anglo-Saxon Eurocentrism. Braudel was very well aware of the growing distance between Europe, that "minuscule continent" and the rest after 1500, a phenomenon that was explained by deep history and by serious comparison. It was certainly not something that was pre-ordained. Braudel did not have a particularly special interest in the history of wage labor, but more implicitly for him is that it is part and parcel of the emergence of market economies.

Braudel attributes real dynamism and innovation to open and transparent markets that are genuinely competitive and not manipulated by only a few individuals. One can find such markets all over Eurasia; in China, Japan, and India. Importantly, according to Braudel, Japan to a certain extent did have independent cities with a powerful bourgeoisie, but China did not. Further, the Chinese state deliberately thwarted capitalism. My point is not that Braudel was right. I believe he was wrong, in particular regarding his rose-tinted idea of transparent markets with equal opportunities for all participants. Nevertheless, he opened the door to including many more places and periods in the

25 Frasie Hertroijs, Hoe kennis van China naar Europa kwam. De rol van jezuïeten en vocdienaren, circa 1680-1795 (Ph.D. dissertation, Vrije Universiteit Amsterdam, 2014).

26 This may easily be seen from the references. In addition, Bas van Bavel wrote to me stating that he had no knowledge of the Kocka-Van der Linden volume when writing his monograph. Only Gareth Austin is involved in two out of the three books, but hardly without cross-referencing.

27 The following mainly after Peer Vries, "Europe and the rest: Braudel on capitalism," in Aufbruch in die Weltwirtschaft: Braudel wiedergelesen, eds. G. Garner and M. Middell (Leipzig, 2014), 81-114. For the reluctant way in which Braudel used "capitalism" see Jürgen Kocka and Marcel van der Linden, eds., Capitalism. The Reemergence of a Historical Concept (London, 2016). 
study of economic development than most of his contemporaries were prepared to.

Partially inspired by Braudel (1902-1985), a subsequent generation of social scientists developed similar ideas criticizing Eurocentrism..$^{28}$ First of all Samir Amin (born in 1931), who himself coined the term in 1988, but also Janet AbuLughod (1928-2013), Andre Gunder Frank (1929-2005), James Morris Blaut (1927-2000), and others. With some success; witness in the first place the "Big Divergence Debate" about the differences between China and Europe initiated by Ken Pomeranz in 2000, and also the debate on the labor-intensive path to economic growth initiated in Japan. Illustrative of the actual situation is the content of the two-volume Cambridge History of Capitalism (2014), the first volume of which is devoted to the spread of capitalism before 1848. It starts with Babylonia in the first millennium всE and includes Greece, Rome, the Silk Road, China, India, the Middle East, and even Africa. ${ }^{29}$

In recent years, a fresh and truly global outlook by Japanese economic historians has quickly gained ground. These historians have suggested the historical feasibility of a labor-intensive path to economic growth as an alternative to the capital-intensive path that supposedly led Britain to the First Industrial Revolution. Kaoru Sugihara, elaborating on the ideas of Akira Hayami and recently in cooperation with Gareth Austin, proposed at least an addition to the traditional theories of economic development.

Instead of explaining the success of market economies from the optimal combination of capital and labor, we have to seriously envision a second option. In Sugihara's own words:

Classical economists ... set the framework of economics by identifying land, capital and labour as the three main factors of production. Thus, in the modern theory of economic growth, the role of labour in industrialization has been mainly discussed in the context of how and in what proportions capital and labour were combined to produce industrial goods ... The second, equally important, assumption that has been shared in the discipline is that labour was abundant, homogenous and disposable at the initial stage of economic development. ${ }^{30}$

28 For a good introduction see Blaut, "Fourteen ninety-two," and his debate with some of them (including Amin and Frank).

29 Larry Neale and Jeffrey G. Williamson, eds., The Cambridge History of Capitalism (2 vols, Cambridge, 2014).

3o Kaoru Sugihara, "Labour-intensive industrialization in global history. An interpretation of East Asian experiences," in Labour-Intensive Industrialization in Global History, eds. 
Because of the highly seasonal nature of agricultural work each year, peasants had enough time to devote their efforts to other types of work. These could include improving existing agricultural practices or working inside the home or elsewhere. In many places throughout Eurasia, peasants successfully experimented in this direction, especially in the period from 1500 to $1800 .{ }^{31} \mathrm{We}$ can observe this process not only in Tokugawa Japan, but also in the Yangtze Delta and in Western Europe, where it is mostly discussed under the title "the industrious revolution," together with the role of women in this process. ${ }^{32}$ For the discussion here, this broadening of cases toward a completely equal footing-implying multi-origin and multilinear histories of waged workmeans nothing less than a historiographic breakthrough for labor history.

This idea also inspired Ravi Palat, who translated Sugihara's ideas from the paddy fields of Japan to those of India between 1250 and $1650 .^{33}$ At the same time, he rejected the inclination to see this monetized and labor-intensive path as a step toward "capitalism" and as an attempt at "assimilating the "historical heritages of every people of the earth' into a master narrative based on patterns of long-term, large-scale social change in Europe and North America." ${ }^{34}$

In 2016, too early to take into account the Sugihara-Austin volume, another excellent example of this fresh global approach to the development of market economies is that of the Dutch mediaevalist Bas van Bavel, who compares in detail the development of factor markets (land, labor, and capital) in Early Medieval Iraq between 500 and 1100, Central and Northern Italy between 1000 and 1500, and the Low Countries between 1100 and 1800 . The equal attention he pays to labor markets and other factor markets is very important, and quite rare in the field. In an epilogue he tentatively combines his insights derived from these three key examples with markets in modern states in England, the

Gareth Austin and Kaoru Sugihara (London/New York, 2013), 20-64, here 20-21. Note also the work of Osamu Saito.

31 Sugihara, "Labour-intensive industrialization," 59. In this context he also refers to Jan Lucassen, Migrant Labour in Europe 1600-19oo. The Drift to the North Sea (London, 1987).

32 Jan de Vries, "The industrious revolutions in East and West," in Labour-Intensive Industrialization in Global History, eds. Gareth Austin and Kaoru Sugihara (London/New York, 2013), 65-84. Note that according to De Vries (p. 8o) there are also important differences between Europe and its East Asian cousin; Elise van Nederveen Meerkerk, "Couples cooperating? Dutch textile workers, family labour and the 'industrious revolution,' c. 1600-180o," Continuity and Change 23 (2008): 237-266.

33 Ravi Palat, The Making of an Indian Ocean World-Economy, 1250-1650. Princes, Paddy fields and Bazaars (Houndmills, Basingstoke, 2015). This book appeared apparently too early to refer to the volume published by Sugihara and Austin in 2013.

Palat, The Making of an Indian Ocean, 223. 
United States, and Western Europe from 1500 onward. His choice of cases resembles that of Fernand Braudel, with the exception of Iraq. ${ }^{35}$

By combining his observations with those of scholars such as, in particular, Fernand Braudel and Jack Goldstone, Van Bavel discerns several cycles of market development, all of which are basically similar, as each cycle contains the following four stages: ${ }^{36}$ First a "market economy," in which factor markets dominate; then a stage of accumulation and growing inequality, and subsequently the stage of "capitalism" with speculation, monopolies, and a close link between capital and the state; and lastly, ending in the decline of the market economy.

Here we see capitalism not as the unavoidable outcome of a unilineal development toward or transition to the market economy, but as a stage in a cyclical process, which has occurred several times and in different places in world history. In his conclusion, Van Bavel takes this cyclical theory even further by including Babylonia and Classical Attica (though with two question marks), the Roman Empire, and Sung China. ${ }^{37}$ Regional variations are especially apparent in the ability of small-scale peasant producers to shift their strategies between factor markets and alternative systems of exchange (in the first place the family, but also commons and guilds) or non-market economic systems. ${ }^{38}$ In other words, labor may follow divergent paths to the subsequent stage.

In addition to Van Bavel, and Sugihara and Austin, a third recent input to the debate about the emergence of market economies is a volume with a title that is at the same time a program: Capitalism. The Reemergence of a Historical Concept. In his introduction, the first editor, Jürgen Kocka, proposes a compound "working definition" of the concept capitalism as a historical process. ${ }^{39}$ Three elements together are crucial in order to define such a process:

- individual and collective actors dispose of rights which enable them to make economic decisions in a relatively autonomous and decentralized way;

- the coordination of the different economic actors takes place primarily through markets and prices ... The commodification of resources and products is central, including the commodification of labor, largely (but not exclusively) in the form of contractual ('free') labor for wages and salaries;

35 Van Bavel, The Invisible Hand? 270-276.

36 Van Bavel, The Invisible Hand? 273-274.

37 Van Bavel, The Invisible Hand? 30-35, 276-287.

38 Van Bavel, The Invisible Hand? 265-266, 282.

39 Jürgen Kocka, Capitalism. A Short History (Princeton and Oxford, 2016), 4-5; cf. Kocka, "Introduction," 21. 
- capital is central for this type of economy. This entails the investment of savings and returns in the present with the perspective of higher gains in the future.

These are not empty words, as Kocka makes clear in a smaller overview where he discusses "Merchant Capitalism," which, he emphasizes, is not simply precapitalist. According to him this term applies to, among others, seventh to eleventh century Arabia, tenth to fourteenth century China, and twelfth to fifteenth century Western Europe. ${ }^{40}$

Marcel van der Linden opens his Final Thoughts in the same volume with the assertion that "Capitalism is and remains a controversial idea." However, at the same time he cites Braudel's famous dictum about capitalism: "Personally, after a long struggle, I gave up trying to get rid of this troublesome intruder ... [If] capitalism is thrown out of the door, it comes in through the window."41 Van der Linden adapts Kocka's definition by emphasizing that "capitalism cannot exist without" commodity production and commodity trade, property rights, money, and competition. Consequently, he recognizes "that capitalism knows many different forms of appearance" including merchant capitalism.

In a detailed and intelligent comment, Gareth Austin calls the three elements of Kocka's definition "dimensions [which] are related but not reducible to each other." ${ }^{\prime 2}$ More importantly, he asserts that many of these dimensions have occurred in the past unrelated to the European genesis of industrialization and asks whether we can use the term "embryonic capitalism" in these cases. $^{43}$

$40 \quad$ Kocka, "Introduction," 25-35, 49, 52, 127. In line with Moses Finley, he hesitates to include Classical Antiquity.

41 Marcel van der Linden, "Final Thoughts," in Capitalism. The Reemergence of a Historical Concept, eds. Jürgen Kocka and Marcel van der Linden (London, 2016), 251-266, here 254-255.

42 Gareth Austin, "The Return of Capitalism as a Concept," in Capitalism. The Reemergence, 207-234, here 215 .

43 Austin, "The Return of Capitalism," 213-214. This rather hesitant formulation may have to do with his warning that for empiricist testing the concept capitalism "defies sensible measurement: we cannot meaningfully rank societies in terms of how capitalist they are, because too many elements are involved." If that is true it seems to contradict his conclusion that "the concept remains heuristically valuable, indeed unavoidable, in many historical contexts." cf. Richard Grassby, The Idea of Capitalism before the Industrial Revolution (Lanham, 1999), 29: "capitalism is difficult to standardize and qualify. Nor is it always clear when quantitative change should be regarded as qualitative, since only the former can be measured objectively." And (p. 64): "Capitalism cannot be defined in ways that make its empirical existence demonstrable or valid ... It cannot serve as a benchmark for operational analysis because it is not quantitative and because its functional mechanism is never described." 
If we take the broad approach by Kocka and van der Linden seriously, many more situations in which economic decisions are made autonomously by actors in markets for commodities and factors-including in particular wage labor-and with a long-term perspective, are more suitable for serious analysis than anybody could have previously envisaged. The first to have done so in a very systematic way was Bas van Bavel, and the labor-intensive path proposition shows a similar potential.

It is irrelevant whether we believe the label "capitalism" is useful, as long as we agree on the characteristics that are necessary in order to include or exclude specific cases for our comparisons. ${ }^{44}$ I consider myself an agnostic in this regard and prefer to stick to the overarching concept of "market economies," some of which might be called "capitalist" from the point at which owners of investment capital acquire a disproportionate power. Only if academia largely agrees on where that point lies, what disproportionate means, and how it can be measured across different places, periods, and cultures, will we be able to use the concept "capitalism" for meaningful analysis. I fear that stage has not been reached yet.

For now, the far less controversial concept of "market economy" provides us with a way out, enabling us to make historical comparisons in a consistent way and encompassing all relevant cases, although I mean "comparison" conceived as "a heuristic tool that offers the historian the closest she can hope to get to controlled, testable hypotheses." ${ }^{25}$ Formulated in the briefest possible way, and as I detail further in the last section of this paper, these cases should encompass all deeply monetized societies because this indicates that wage labor there plays a substantial enough role to be considered.

\section{3}

\section{The Taxonomy of Labor Relations as a Tool to Study Work Worldwide}

The great gains of the last decades so far discussed, regard the conceptual escape from insular Anglo-centrism and from Eurocentrism, but are still restricted to market economies. For a genuine and all-encompassing concept of work, at the IISH in approximately 2005 we realized that it was also necessary

44 However, considerations for including a conceptual term not only have to do with criteria, whether they are essential or not. The load of connotations that a term may have also plays a role. Personally, I think the term capitalism has become overloaded, which hinders rather than fosters a straightforward application. Attempts at redefining do not take away the noise made by all previous definitions and their applications.

This formulation by Epstein, "Rodney Hilton," p. 260. 
to examine seriously all forms of work performed outside the market. ${ }^{46}$ The Tillys' emphasis on the significance of unpaid household work offered a first possibility, but it was rapidly evident that more was necessary if we wanted to include all historical societies. ${ }^{47}$

According to classical authors, the Greeks had an inborn urge for liberty, from which followed a monetized society with free labor markets, in addition to slave labor. Their Persian enemy, by contrast, was doomed to a hierarchical society, characterized by unfree labor. ${ }^{48}$ This contrast between "us," working from free will, and "the other," working only on command, was transmitted into the Renaissance and Enlightenment, and through the discovery voyages in the Pacific, supplemented by the concept of the "noble savage." Nineteenth century consensus only viewed Europe, subject to an internal dynamic, as evolving seemingly spontaneously from paradisiacal primitivism via feudalism to capitalism, and in the end to socialism. All the other, more primitive, societies were stuck in the phase of slavery, Asiatic despotism, or similar compulsory systems in which work was organized. A partially less negative image of the "other" societies was proposed by Max Weber, who demonstrated that in classical Egypt, the obligations of the Pharaoh's subjects were at least partially balanced by spiritual and material top-down obligations. For Mesopotamia, the great pre-Columbian societies in the Americas, and elsewhere, the same sort of interpretations have gained ground, especially in the theoretical work of Karl Polanyi. He stresses that such "centristic" societies depended not only on labor obligations by the community and taxation in kind, but equally on "redistribution."49

It is unfortunate that in his zeal to show how unimportant the market had been in the past, Polanyi overstretched his arguments, such as for example in his famous and detailed study on Dahomey. ${ }^{50}$ As a consequence, his attempts

46 The core group consisted of Karin Hofmeester, Christine Moll-Murata, Marcel van der Linden, and myself.

47 Already in Van der Linden and Lucassen, Prolegomena, 9-10 "unpaid" and "autonomous" is said to "include household labor and other forms of subsistence labor" and "unpaid" and "heteronomous" work to "include feudal serfdom and chattel slavery," but both possibilities are not further elaborated.

48 Page Dubois, Slavery. Antiquity and its Legacy (London/New York, 2010), 54-66; cf. Catharina Lis and Hugo Soly, Worthy Efforts: Attitudes to Work and Workers in Pre-Industrial Europe (Leiden/Boston, 2012), Ch. 1.

49 Grassby, The Idea of Capitalism, 20-21; Jan Lucassen, Outlines of a History of Labour. IISH Research Paper $5^{1}$ (Amsterdam, 2013), 8-9, 20-21; Austin "The Return of Capitalism," 214-215. For Polanyi's influence on Finley see Lis and Soly, Worthy Efforts, 54-58.

$5^{\circ}$ Karl Polanyi in collaboration with Abraham Rotstein, Dahomey and the slave trade; an analysis of an archaic economy (Seattle, 1966). 
to work out in a more informed and up to date way the variety of labor relations outside the market have also had less impact on the theorizing about taxonomies of work than they deserve. The same applies to a number of theoreticians of the concept of "peasantry," for example Chayanov, who tried to downplay the market involvement of the Russian peasants around 190o.51

All of these scholars - regardless of their shortcomings - provided us with the inspiration to come up with a proposal for a taxonomy of all types of human relations regarding work. ${ }^{52}$ For reasons of methodical discipline, it tries to embrace all people living in a given community at a given time. Therefore the first and basic distinction is between those who work (according to the definition given above) and those who do not. A second distinction is made among those who do or do not work to produce goods or services for the market. Subsequent distinctions are made within these main categories.

This taxonomy, however, has never been an aim in itself. It is nothing more or less than a tool that enables us to compare, for any geographical area at any moment in time, the proportional distribution of labor relations in order to compare different cases, to establish commonalities and differences, and to explain continuity or change. We see this as one of the indispensable key instruments for a labor historian. In this respect we are not original, as may be exemplified by the detailed analysis of labor relations in London around 1900 by Charles Booth (1840-1916) and of the German Empire by Werner Sombart (1863-1941). Much later, Charles Tilly revived this approach covering Europe outside Russia from the sixteenth century onward. ${ }^{53}$

To date, the main result of this huge project is the awareness that contrary to earlier strands of labor history, major changes in labor relations as described here often take a long time, usually several generations, and they take place only gradually. Members of peasant households may perform wage work for part of a year or even for part of a day. Such combinations at the level of one person or one household may function successfully over many generations.

$5^{1}$ A.V. Chayanov, The Theory of Peasant Economy, eds. Daniel Thorner, Basile Kerblay, and R.E.F. Smith (Homewood, IL, 1966); Theodor Shanin, ed., Peasants and Peasant Societies. Selected Readings (Harmondsworth, 1971).

$5^{2}$ https://collab.iisg.nl/web/labourrelations. Especially see Karin Hofmeester, Jan Lucassen, Leo Lucassen, Rombert Stapel, and Richard Zijdeman, "The Global Collaboratory on the History of Labour Relations, 1500-2000: Background, Set-Up, Taxonomy, and Applications" (2015). Available at http://hdl.handle.net/10622/4OGRAD.

53 Charles Booth, Life and labour of the people in London (14 vols., London, 1902-1904); Werner Sombart, Das Proletariat. Bilder und Studien (Berlin, 1906); Charles Tilly, "Demographic Origins of the European Proletariat," in Proletarianization and Family History, ed. David Levine (London, 1984), 26-52. 
The putting-out system in the rural textile production is one of the best-known examples. In fact, under close scrutiny, the combination of different labor relations within one household and often one person seems to have been the rule until very recently, and this certainly is still the case if we include unpaid work within the household.

By contrast, various forms of serfdom and slavery, and similar legally based systems of labor mobilization, have a much longer lifetime and may also coexist with free labor markets for categories of workers with a different status. As long as this distinction between fundamentally and legally different categories of human beings may be upheld successfully, free and unfree labor relations can co-exist.

\section{Wage Labor: Long-Term Historical Developments}

With the conceptual and analytical tools forged in the past decades as described in the previous sections, it is now finally possible to come up with a new narrative of the long-term history of work worldwide. The aim here is to concentrate on wage labor in market economies-after all the classic terrain of labor history - and more specifically on the significance of coin circulation in different parts of the world for the history of work and of labor relations.

For most of human history, work was organized in small groups consisting of only a handful of households. Only many thousands of years after the first agricultural societies emerged in the Middle East did production surpluses become large enough for occupational specialization in certain households. The concomitant exchange of goods and services required more elaborate rules than those of obligation and affection that govern labor relations inside households. Such an exchange outside the reciprocal household circle can be organized locally or within larger communities. Locally, agreements can be made by obliging artisans such as blacksmiths, carpenters, potters, or priests to provide for whatever their farming co-villagers need in return for their share in the harvest of these farmers (for example in the Indian jajmani system). When not dozens or hundreds, but thousands or more households were involvedand not only artisans and peasants, but also specialized farmers-cities, city states, and similar polities appeared, based on obligation systems in return for maintenance. Well-known examples of these tributary labor relations include the old Mesopotamian city and later territorial states, and also classical Egypt, classical China, the Indus civilizations, and the pre-Columbian states. ${ }^{54}$ Here

54 Note that there are also different usage of this term, see Amin's "tributary mode of production." 
we can also find the earliest examples of waged work, paid in kind, as the soldiers of the Assyrian Empire demonstrate. However, apart from the military, there was no labor market more generally, as all the other households were aware of their obligations to as well as what they could expect from the polity.

This specialization process could reach such levels of intensity that the exchange of goods and services by fixed obligations, supervised by the polity and a shared ideology, evoked an alternative societal model. That was the market economy, which went hand in hand with the introduction of mediums of exchange. This innovation, and in particular (but not necessarily so) the introduction of coins induced the monetization process. It is not by chance that I prefer the term "introduction" rather than invention, as invention suggests a genius coming up with something new, the utility of which has to be demonstrated to his or her fellow citizens. Monetization is instead the answer to a broad societal demand for a convenient means of exchange, as its particular history suggests. Remarkably, monetization processes started at three different places around the same time, but most likely independent of each other as the regionally totally different material character and designs suggest.

\subsection{Monetization and Deep Monetization}

Around 500, before the Common Era, coins were introduced in the eastern Mediterranean, Northern India, and East China. From there, coinage proliferated quickly all over the subtropical and moderate parts of this huge land mass and of adjacent northern Africa, and after 1500 to the Americas and finally to tropical Africa and Oceania. ${ }^{55}$ Although highly successful, this innovation did not simply conquer the world after its introduction. It instead shows a history of leaps and bounds of alternating periods of monetization and demonetization. Monetization in China, after its initial success between $35^{\circ}$ BCE and $200 \mathrm{CE}$, was followed by periods of major demonetization between 600 and 1000 and again between 1200 and 1500 . This periodization differs from other parts of Eurasia. Interestingly, in Northern India and Western Europe demonetization took place at a similar time, between around 400 and 1100.

55 Jan Lucassen, "Deep Monetization in Eurasia in the long run," in Money, Currency and Crisis. In Search of Trust 2000 BC to AD 200o, eds. Bert van der Speck and Bas van Leeuwen (London, 2018, forthcoming). For preconditions and actual monetization as well as wage levels in first century вС в Babylonia, see Michael Jursa, "Babylonia in the first millennium ВСЕ-economic growth in times of empire," in The Cambridge History of Capitalism, eds. Larry Neale and Jeffrey G. Williamson (2 vols, Cambridge, 2014), 24-42. For England, see additionally Christine Desan, Making Money. Coin, Currency, and the Coming of Capitalism (Oxford, 2014). Also, several contributions to Martin Allen and D'Maris Coffman, eds., Money, Prices and Wages. Essays in Honour of Professor Nicholas Mayhew (Houndmills, Basingstoke, 2015). 
Crucially, after initial periods of somewhat different length, in all three original cases medium and small coins of low value — or even with a fiduciary value-were produced in large quantities. In that way, circulation patterns were adapted to the payment of wages and to their usage by wage earners to pay for goods and services in shops and market places. Consequently, the study of monetization may help us to understand the extension of waged work and labor markets in different important economic centers of Eurasia for the last 2,500 years.

Most narratives of the spread of monetization are restricted to the Mediterranean and Europe, and at the same time suppose that the concomitant "capitalist spirit" could exclusively emerge there. In the restricted framework of this essay, I provide three examples from China, Japan, and India thatto the contrary-instead suggest similarities between the different economically well-developed parts of Eurasia. The Chinese historian Sima Qian (c. 145-86 вСЕ) summarized the developments of the preceding centuries (exactly those in which the first monetization wave occurred) as follows:

Society obviously must have farmers before it can eat; foresters before it can extract timber resources; artisans before it can have manufactured goods; and merchants before they can be distributed. But once these exist, what need is there for government directives, mobilizations of labor, or periodic assemblies? Each man has only to be left to utilize his own abilities and exert his strength to obtain what he wishes. Thus, when a commodity is cheap, it invites a rise in price; when it is very expensive, it invites a reduction. When each person works away at his own occupation and delights in his own business then, like water flowing downward, goods will naturally flow forth ceaselessly day and night without having been summoned, and the people will produce commodities without having been asked. Does this not tally with reason? Is this not a natural result? ${ }^{56}$

This early eulogy of markets by Sima Qian has a moral companion in the following observation by the Japanese Mino Masataka published in 1733; as if it was a merger of the proto-Smithian Sima Qian and the Weberian Protestant ethic:

$5^{6}$ Anthony J. Barbieri-Low, Artisans in Early Imperial China (Seattle/London, 2007), 43 (translation Burton Watson). Cf. Richard von Glahn, Fountain of Fortune. Money and Monetary Policy in China, 10oo-17oo (Berkeley etc., 1996), 26-43. 
Though Confucianism, Buddhism and Shintoism are different respectively, in any case the fundamental value is sincerity. It is the teachings of rewarding good and punishing evil, governing the state and effecting universal peace, and setting the people at ease. Unselfishness, honesty, sympathy, ad mercy are all good attributes ... In a country there are generally three treasures, namely land, people, and politics ... persons have to be in charge of property from an ancestor and to worry about bringing up parents, wives, children and the whole family. And they must work hard at official affairs without complaining of adversity. Consequently they have no time to be glad for their lives, to fear death, or to enjoy amusements indoors. ${ }^{57}$

We are also given a glimpse of the filtering down of this spirit from India in some of Abdur Rahman's poems (the Nagar Shobha, composed while at Akbar's court at Lahore, 1580-1583) about sixty-six women, for each of whom he combines their erotic attractions and their economic activities. Economic attitudes are possibly most clearly visible in his verses devoted to the wife of the cowherd:

The Gujarin, carrying a pot of curd on her head, is exceptionally beautiful. The spilling of the curd is like the nectar of the senses, but she gives not any; She jokes with the customer and freely makes promises first stating her own price and then that of the curd. ${ }^{58}$

\subsection{Deep Monetization and Global Labor History}

The question now arises as to what the relationship is between variations in the intensity of monetization and the development of wage labor. ${ }^{59}$ Therefore, we have to distinguish more precisely between coins of different metals and weights. There is a huge difference between on the one hand the usage of denominations that are important for long distance trade (the most valuable pieces made of gold or silver) and on the other, the small silver, copper, and other non-precious metal denominations used by the common man.

In my recent work I have proposed using the term "medium monetization" for situations in which denominations equaling one day's payment are

57 Bettina Gramlich-Oka and Gregory Smits, eds., Economic Thought in Early Modern Japan (Leiden/Boston, 2010), 63-64.

58 T.C.A. Raghavan, Attendant Lords. Bairam Khan and Abdur Rahim Courtiers and Poets in Mughal India (Delhi, 2016), 98.

59 Holton, The Transition from Feudalism, 32, formulated it as follows: "Does the market economy also produce a market-oriented society?" See also $39 \mathrm{ff}$. 
abundantly available. Deep monetization then applies to situations when coins equaling the value of one hour's work or less are readily available. To be more precise, the value of these denominations should be more than five times the value of an hourly wage for a skilled worker in order for a society to qualify as being deeply monetized. There is no space here to explain why five times circulating per capita seems to be an acceptable threshold. ${ }^{60}$ However, no matter what the precise threshold may be, this approach to deep monetization provides us with a practical instrument to measure and compare the intensity of monetized exchange among common people who were wage workers, or small independent producers receiving advances for their tasks at hand. These are the people who urgently needed these coins for frequent - that is, daily or weekly-payments. Much more urgently than the well-to-do who enjoyed sufficient credit to pay their bills at much larger intervals because their assets enabled them to obtain credit from shop keepers and merchants. The common man lacked property, and therefore enjoyed only very limited credit and thus used small coins most frequently.

This can be illustrated by an example from fourteenth-century India, where small denominations (half and quarter jital coins) equaling one hours work or less appeared. Firoz Shah, Delhi Sultan 1351-1388, introduced these as follows:

if poor people bought something from the market and a balance in half or quarter jitals was left of the amount paid, the shopkeeper would not have the quarter change. If he demanded it from the shopkeeper how could he be paid when no such coin existed?61

Under the Suri Dynasty in Delhi (1538-1554) and under the Mughal Emperor Akbar (1556-1605), massive numbers of copper coins were produced in several small denominations. It is no wonder that the early Portuguese travelers in the subcontinent were deeply impressed by the commercial skills of the Indians, which they esteemed as being higher than those of the Italian merchants. In his description of the traders of Gujarat, Tomé Pires in his Suma Oriental (1512-1515) calls the Indian traders:

6o For the threshold see: Jan Lucassen, "Deep Monetization: The Case of the Netherlands 1200-1940," TSEG 11 (2014): 73-121, 75; Lucassen, "Deep Monetization in Eurasia in the long run."

61 Najaf Haider, "Fractional pieces and non-metallic monies in medieval India (1200-1750)," in Money in Asia (1200-190o). Small Currencies in Social and Political Contexts, eds. Kate Leonard and Ulrich Theobald (Leiden/Boston, 2015), 86-107, here 90, quoting Firoz Shah's court historian Shams Siraj Afif. 
men who understand merchandise; they are so properly steeped in the sound and harmony of it that the Gujaratees say that any offence connected with merchandise is pardonable ... Those of our people who want to be clerks and factors ought to go there and learn, because the business trade is a science in itself. ${ }^{62}$

Consequently, the long-term history of wage labor may gain much from measuring deep monetization, especially in situations where archaeology provides good insights if written sources are meagre or lacking altogether. Archival documents on coin production figures are only available for China from the Han period onward and for Western Europe from the thirteenth century onward. Both types of information combined enable us to reconstruct developments in the remuneration of work much more accurately than before. I end by pointing to two instances when evidence about coin circulation and wage labor combined point to shifting labor relations.

To begin with in England, where as we have seen, traditional historiography greatly emphasized the phenomenon of feudalism, but where this new approach instead emphasizes monetization and the emergence of labor markets. Bolton characterizes the English society around 1250, where 40 pennies per head were in circulation, as follows:

By the mid-thirteenth century the concentrated money supply had probably reached the critical point that would allow coins to be used as the normal medium or agent of exchange. They could be used to buy and sell goods, to pay wages and other dues that peasants owed to lords. They could be collected as taxes and offered or demanded in lieu of feudal military service, and kings could now pay their much larger armies with coins. ${ }^{63}$

Recent archaeological evidence confirms this image. ${ }^{64}$ According to Chris Dyer, in the fourteenth century,

The proportion of people who obtained most of their living from wage work must have exceeded one third over the whole country, rising to twothirds in parts of the east. There were concentrations of wage-earners in

62 Quoted in Blaut, Eight Eurocentric Historians, 93.

63 J.L. Bolton, Money in the Medieval English Economy, 973-1489 (Manchester, 2012), 27, cf. $132-135$

64 Lucassen, 2018. 
large towns; in York for instance, 32 per cent of the contributors to the poll tax were called servants. ${ }^{65}$

The second monetization phase in China took off briskly under the Song just before the year $1000 .{ }^{66}$ Not much later, compulsory work for the state was converted into a tax to be paid in cash, and economic progress was so impressive that some authors think that Song China was just a "hair's breadth" away from a genuine industrial revolution. In the twelfth and thirteenth century, these developments changed and only after the Ming, which increased "bond servitude," what may be called a third important wave of monetization followed in eighteenth-century China. At this time, wage labor in various industrial sectors such as mining, printing, porcelain making, and shipbuilding also increased.

Although the history of monetization has been known more or less for a very long time (India possibly excepted), it is the novel story of deep monetization that is important here. ${ }^{67}$ Instead of attributing monetization to longdistance trade, it is instead the emergence of labor markets that brought about deep monetization. This new evidence about the circulation patterns of small coins enables us to extend substantially the history of waged work in time and space. The history of wage labor did not start in the West a few centuries ago or even in the Middle Ages. In fact, it started in the major economic centers of Eurasia 2,500 years ago.

In Sum

As a result of the efforts of so many, but especially of the common efforts of Marcel van der Linden and his colleagues at the research department of the IISH, and those very many engaging in and attached to its projects over the last decades, global labor history may now be seen in a different way than before.

65 Nicholas Mayhew, "Wages and Currency: The Case in Britain up to 160o," in Wages and Currency. Global Comparisons from Antiquity to the Twentieth Century, ed. Jan Lucassen (Bern, 2007), 211-220, here 213-214 (quoting Dyer). For the European continent see Bas van Bavel, "Rural wage labour in the sixteenth-century low Countries: An assessment of the importance and nature of wage labour in the countryside of Holland, Guelders and Flanders," Continuity and Change 21 (2006): 37-72; Bas van Bavel, "The transition in the Low Countries: Wage labour as an indicator of capitalism in the countryside, 1300-1700," Past and Present 195 (2007): 286-303; Van Bavel, The Invisible Hand?, 159-164, 174-177; cf. Tilly's estimate of one quarter for Europe as a whole around 1550, as quoted in Kocka, "Introduction," 129.

66 William Guanglin Liu, The Chinese Market Economy, 10oo-1500 (Albany, 2015).

67 See also Holton, The Transition, 39-46. 
Tentatively the long-term history of work may provisionally be reformulated in the following way:

- Occupational specialization among agriculturalists, much more than the exigencies of long distance trade, brought about the emergence and unfolding of market economies, including labor markets and the demand for means of exchange, mostly coins.

- Such conditions emerged in several places and at several times over the last 2,500 years, often independently, sometimes mutually influenced. Leaving aside for a moment earlier periods of monetization and demonetization, monetized market economies with concomitant ideologies have been in existence uninterruptedly until now in India and in the West for the last nine centuries, and in China for the last four centuries.

- Most alternative ways of organizing work in a society with occupational specialization-such as for example state-led redistribution (pharaonic Egypt and pre-Columbian America) - have proved to be less successful in the very long term, with one exception: non-monetary reciprocity of goods and services within the household, kin groups, and similar small-scale social entities. This organizational type has always coexisted in a most intimate way with distribution via markets and it continues to do so. Marketization and monetization by no means dominate all human labor relations.

- Until one to two centuries ago, many if not most polities allowed free and unfree labor to co-exist. ${ }^{68}$ Since then this situation has occasionally recurred, sometimes even on a massive scale, but always defined as exceptional; as punishment or as an emergency in war time (for example Russia under Stalin, Germany under Hitler, or China under Mao).

- Wage labor is certainly not a type of work of last resort where income by definition is minimal and barely enough to avoid starvation. Comparative and long-term research into wage levels shows major variations in remuneration levels resulting in many low, but also medium and high, standards of living. ${ }^{69}$

- Wage labor is not only flexible in its relationship with reciprocal household labor, but also shows many variations (time and piece waged work, subcontracting, share cropping, or small independent production based on advances). Furthermore, it may vary in intensity (for example the

68 Kocka, "Introduction," 136-137.

69 Lucassen, Outlines; Jursa, "Babylonia," 37; Sevket Pamuk, "Institutional change and economic development in the Middle East, 700-1800," in The Cambridge History of Capitalism, eds. Larry Neale and Jeffrey G. Williamson (2 vols, Cambridge, 2014), 193-224, here 195-196; Christopher Dyer, "A Golden Age Rediscovered: Labourers' Wages in the Fifteenth Century," in Money, Prices and Wages. Essays in Honour of Professor Nicholas Mayhew, eds. Martin Allen and D'Maris Coffman (Houndmills, Basingstoke, 2015), 180-195. 
industrious revolution or the labor-intensive path to industrialization as explained below).

- Favorable wage levels were not only the result of demand for labor exceeding supply, such as for example after the Black Death in many parts of Eurasia, but also of collective action of wage workers, which to date can be testified by many examples, though not yet by systematic research. ${ }^{70}$ Wage laborers were not by definition defenseless victims of the market.

- Lastly, wage laborers use a large repertoire of actions to foster their interests in the market. They do so in two ways: individually (by changing job or employer locally, or by migration temporarily or permanently ${ }^{71}$ ) and collectively. In the latter case they need to use the existing political structures, which has happened most successfully so far in different types of welfare states.

Early on, some historians already recognized that market economies have a long pedigree. In general not or hardly aware of the implications for labor history, they have argued at the same time that earlier and non-European market economies are very different from "modern" forms. ${ }^{72}$ By implication, these pre-capitalist market economies supposedly also have much less, or maybe no relevance at all in terms of understanding wage labor here and now. This claim can no longer be supported, since our knowledge of the history of paid labor has grown so substantially. There is a substantial gap between this new narrative and the classic theoretical framework that is unilinear and highly Eurocentric. By comparison, the new evidence requires a framework encompassing multi-origin and therefore multilinear developments. Nevertheless, we should not throw out the baby with the bathwater. The great virtue of traditional labor history lies in its extensive analysis of collective action among wage laborers. ${ }^{73}$ Combined with private strategies, as evident from social and geographical mobility, ${ }^{74}$ these are aspects of labor history that now can and have to be applied to a much wider field of evidence; and the results can be ploughed back into contemporary studies. No doubt this will yield a rich harvest in the near future of this discipline.

70 Jan Lucassen, "Working at the Ichapur Gunpowder Factory in the 179os," Indian Historical Review 39 (2012): 19-56 and 251-271.

71 For labor turnover in medieval England see Richard Britnell, "Labour Turnover and Wage rates on the Demesnes of Durham priory, 1370-1410," in Money, Prices and Wages. Essays in Honour of Professor Nicholas Mayhew, eds. Martin Allen and D'Maris Coffman (Houndmills, Basingstoke, 2015), 158-179.

72 Grassby The Idea of Capitalism.

73 For an excellent overview, see Marcel van der Linden, Workers of the World. Essays toward a Global Labor History (Leiden/Boston, 2008).

74 Lucassen, Outlines; Jan Lucassen and Leo Lucassen, eds., Globalising Migration History. The Eurasian Experience (16th-21st centuries) (Leiden/Boston, 2014). 